\title{
The Political Economy of India’s Fiscal Federal System and its Reform
}

\section{Govinda Rao and Nirvikar Singh \\ Revised August 2006}

\begin{abstract}
This article examines recent and potential reforms in India’s fiscal federal system. We summarize key federal institutions in India, including tax and expenditure assignments, and mechanisms for Center-state transfers. We discuss the institutional process by which reforms can and do take place, including the role of academics, political influences, and especially institutions such as the Finance Commission. In contrast to the past, recent commissions have played a greater role in articulating an agenda for fiscal federal reform, which then proceeds through political bargaining. This change has taken place in the context of, and been influenced by, broader economic reform in India.
\end{abstract}

Keywords: intergovernmental transfers, economic reform, federalism, regional inequalities

JEL codes: P26, P35, H1, H7

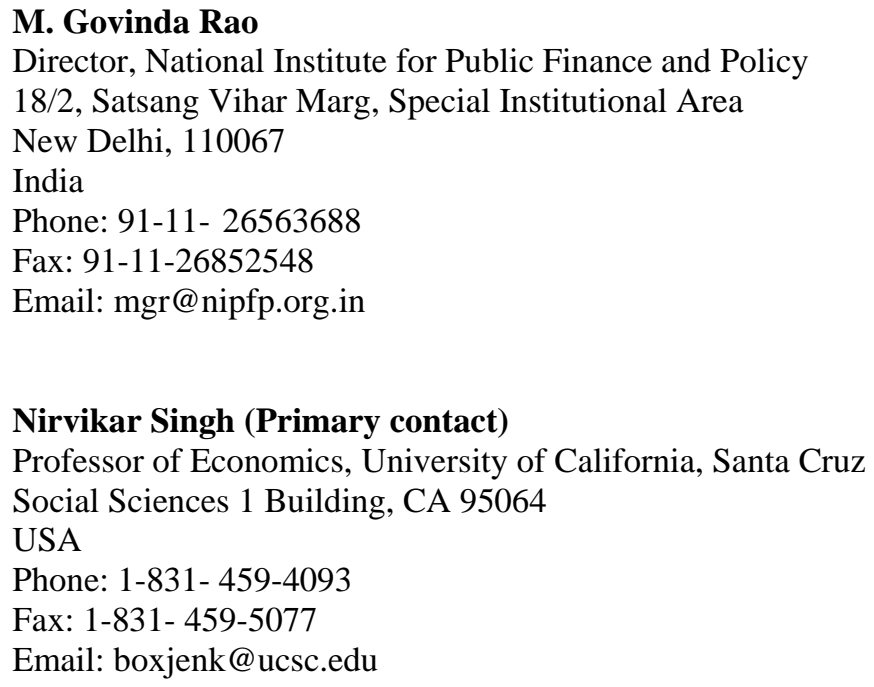




\section{The Political Economy of India's Fiscal Federal System and its Reform}

Economic reform, where the term is typically used to indicate a reconsideration of boundaries between state action and market forces, has been a significant feature of the world economy since the 1980s, spurred by the success of many East Asian economies, and by the collapse of the Soviet Union. Many of the large countries grappling with economic reform include, unsurprisingly, those with federal systems of various kinds, e.g., Brazil, China, India, Indonesia, Russia, and South Africa. It is natural that there would be special challenges for implementing change in countries with multiple layers of political authority and divided sovereignty. There are difficulties in intergovernmental bargaining that result from federal structures, as well as the greater complexity and range of institutions that must be considered for reform. Arguably (e.g., Wibbels, 2005), the literature on federalism has not sufficiently addressed the issue of reform in developing countries with federal structures. Nor has there been adequate attention to the political determinants of federal institutions, and how these shape the reform process (e.g., Wibbels, 2005; Rodden, 2006a).

This article provides an analysis of India's fiscal federal institutions in the context of that country's economic reform. It uses a political economy perspective on the working of India's federal system to examine past reforms in the system of intergovernmental transfers, including the institutional process of these reforms. The political feasibility of possible structural reforms in India's fiscal federal institutions is discussed, using the examples of tax assignments, decentralization to local governments and a move toward market borrowing by state governments. India is an interesting candidate for study, because of its size, diversity and institutional complexity. While 
every country has specific institutions, so that lessons from case studies must be applied with caution, the discussion in this article may be seen as contributing to the broader research project of understanding the dynamics of federal systems, especially in developing countries (e.g., Wallack and Srinivasan, 2005). In particular, this article argues that reform of India's fiscal federal institutions has been driven by greater regional political competition, and has proceeded by a combination of political agenda-setting, technocratic advice, and political bargaining, with new institutions created, and existing federal institutions being adapted to the new environment.

\section{FEDERAL INSTITUTIONS IN INDIA}

India is comprised of 28 states and seven "Union Territories" (including the National Capital Territory of Delhi). All the states have elected legislatures and chief ministers in the executive role, though state governors exercise some powers. Because many Indian states are quite large, with the largest dozen being comparable in population to larger European countries, devolution of powers to the states without any further decentralization below that level still represents a relatively centralized federation. In practice, devolution to both the states and substate (local) government bodies was weak before the 1990s.

The primary expression of statutory constitutional authority in India comes through directly elected parliamentary-style governments in the national and state arenas, as well as nascent directly elected government bodies in various local jurisdictions. The rise of regional parties, and of explicit coalitions in the national Parliament, have together led to some decentralization in legislative governance. Other dimensions of governance 
structures that embody aspects of federalism include the bureaucracy and judiciary: both are relatively centralized.

What distinguishes federalism from general decentralization is the assignment of inextinguishable powers to subnational governments (Breton, 2000). Assignments include important non-fiscal dimensions, but control over how public resources are raised and spent represents a crucial aspect of any federal system. The Indian Constitution assigns the powers and functions of the Center and the states, in Union, State and Concurrent Lists. All residuary powers are reserved to the Center. The assignments are fairly typical of federal nations. The functions of the central government relate to those of defense, those required to maintain macroeconomic stability, promote international trade and relations, exploitation of major minerals, and those having implications for more than one state. The major subjects assigned to the states include public order, public health, and agriculture. In practice, the states assume a significant role for subjects in the concurrent list, including education, transportation, and social insurance.

The assignment of tax powers in India is based on a principle of separation, that is, tax categories are exclusively assigned either to the Center or to the states. Most broad-based taxes have been assigned to the Center, including taxes on income and wealth from non-agricultural sources, corporation tax, taxes on production, and customs duties. A long list of taxes is assigned to the states. However, only the tax on the sale of goods has been significant for state revenues. The separation of income tax powers between the Center and states based on whether the source of income is agriculture or not has opened up avenues for evasion of the personal income tax. Also, although taxes on production (central excises) and sale (state sales taxes) are separate, they tax the same 
base, historically causing cascading of rates and effectively crowding out state taxes.

Finally, the states have been allowed to levy taxes on the sale and purchase of goods but not services. This has also led to tax evasion.

The result of India's assignments and implementation of tax and expenditure authorities has been a substantial vertical fiscal imbalance, with well over a third of state expenditures having to be covered by transfers from the Center. The Constitution recognized that its assignments would create imbalances - both vertical, among different levels of government, and horizontal, among different units within a sub-central level. Therefore, it originally provided for the sharing of revenues from certain centrally levied taxes (particularly the personal income tax) with the states, and grants to the states from the Consolidated Fund of India. The tax shares of the Center and of each state are determined by the Finance Commission, which is appointed by the president of India every five years. In addition, the Finance Commission is required to recommend grants to states as needed. So far, twelve Finance Commissions have made recommendations, mostly accepted by the central government. However, the functioning of these commissions has been criticized for being too restricted in scope, and for using methodologies for determining transfers that were deficient in their consequences for equity and incentives. ${ }^{1}$ More specifically, on the last point, the use of grants to fill revenue-expenditure gaps claimed by the states has created "soft budget constraints" for the states, and obvious disincentives to maintain fiscal discipline.

A notable feature of India's federal fiscal arrangements is the existence of multiple channels for Center-state transfers. As noted, the Finance Commission decides on tax shares and makes grants. Second, the Planning Commission, a central government 
body created by an Act of Parliament, gives grants for implementing five-year (indicative) development plans. Finally, various ministries give grants to their counterparts in the states for specified programs, either wholly funded by the Center (central sector projects) or requiring the states to share a proportion of the cost (centrally sponsored schemes).

Historically, as development planning gained emphasis, the Planning Commission became a major dispenser of funds to the states. Before 1969, plan transfers were project-based. Since then, a consensus formula decided by the National Development Council (NDC) has been used. ${ }^{2}$ Central ministries can influence states' outlays on selected items of expenditure through specific-purpose transfers, with or without varying matching requirements. These are nominally monitored by the Planning Commission. There are more than 200 such central sector and centrally sponsored schemes, and periodic attempts to consolidate them into broad sectoral programs have had limited success. The current share of Finance Commission transfers in total transfers to the states is about 64\%, with Planning Commission and ministry transfers making up roughly equal shares of the rest.

\section{THE POLITICAL ECONOMY OF CENTER-STATE TRANSFERS}

We interpret the evolution of India's institutions for Center-state transfers as follows. The Finance Commission was envisaged in the Constitution as the key institution responsible for dealing with fiscal imbalances between the Center and the states, as well as among the states. Instead, its role has been circumscribed by the working of the Planning Commission, outside the Finance Commission’s terms of reference. 
Furthermore, as Planning Commission transfers became formulaic, there was a tendency to move toward using discretionary grants determined by the central ministries. Thus, the overall tendency seems to have been for the central government to try to exercise as much political control as possible over transfers to the states. Also, within each channel for transfers, there is evidence that there are attempts to influence the outcomes of the process. ${ }^{3}$ Later in this article, we examine issues of how such influence effects might be moderated through institutional reform, in cases where they are believed to lead to inefficiencies, or failure to meet equity objectives in the transfer system. We first summarize the theory and evidence for political-influence factors in the system of explicit intergovernmental transfers.

In the large literature on the political economy of federalism, some analysts use bargaining models to focus on the formation and stability of the federation itself (e.g., Rao and Singh, 2002, and references therein). An alternative branch of literature examines distribution and redistribution in the context of existing nations, without the threat of secession or breakup being considered. Again, bargaining perspectives are important, with differing emphases on particular institutions, including legislative structures (e.g., Inman and Rubinfeld, 1997; Breton and Scott, 1978; Baron and Ferejohn, 1989), voter ideological positions (e.g., Dixit and Londregan, 1998; Dasgupta, Dhillon and Dutta, 2001), and representation structures and intergovernmental transfer mechanisms (e.g., Kletzer and Singh, 1997, 2000).

The theoretical models have been the basis for recent attempts to estimate political influences on Center-state transfers in India (e.g., Rao and Singh, 2002; Biswas and Marjit, 2000; Dasgupta, Dhillon and Dutta, 2001, Rao, 1979). These models use 
different categories of transfers (by state) as dependent variables, and measures of economic and political power as explanatory variables. Examples of the political influence variables used in various studies include the ideological leanings of parties in power and the degree of political stability (Rao, 1979), the proportion of the ruling party's members of Parliament (lower house only) ${ }^{4}$ coming from each state, the number of cabinet ministers from each state, a dummy variable measuring whether the same party was in power at the Center and in the state receiving the transfers, and a measure of the closeness of each state's legislative assembly election. The first two variables can be viewed as measuring "power," the third as reflecting whether the state might "swing” in a favorable direction as a result of transfers, .and the last as capturing "alignment.” On balance, the studies suggest the importance of political influence as measured above, as well as economic power, in affecting the observed pattern of Center-state transfers in India, and in directions generally consistent with the theoretical models. ${ }^{5}$

In fact, the empirical analyses above were restricted to explicit transfers. Political economy considerations can also work through a variety of additional channels. Various types of controls and regulations, which are partly inherent in a planned development strategy and were partly introduced to meet the exigencies of a scarcity ridden economy in the 1950s, alter regional resource allocation from what would have been determined by the market. The Center's regional policies and own investments have also determined resource flows across India's states. Often, these implicit resource transfers (as opposed to explicit transfers made through various channels) were unintended, as in the case of India's freight-equalization scheme. ${ }^{6}$ Financial repression, allocation of loans at below market rates of interest to states, mandated allocation of loans at below market interest 
rates to priority sectors, and an origin based tax system and inter-state tax exportation have also resulted in significant implicit transfers with differential regional impacts (Rao, 2000a). Political economy factors can also manifest themselves in the design of the tax system at the state level, with regional implications. In particular, origin-based sales taxes levied by the states have caused significant interstate tax exportation.

The recent empirical findings on the political economy of Center-state transfers are of greater importance in the context of other empirical work that suggests that regional inequality in India has been growing (e.g., Cashin and Sahay, 1996; Nagaraj, Varoudakis and Veganzones, 1998; Rao, Shand and Kalirajan, 1999), and that political economy factors can dampen equalization across states through intergovernmental transfers (Rao and Singh, 2002). Furthermore, increases in the potential for greater disparities across states, as a result of market-oriented reforms, put more of the burden on an effective system of Center-state transfers. This suggests a greater focus on possible reforms in the transfer system. An example of how the process of institutional reform can work comes from the case of tax-sharing arrangements. As noted earlier, the Constitution originally specified certain categories of centrally collected taxes that were to be shared with the states, including personal income taxes and excise duties, but not any surcharges, or corporate taxes. Over time, personal income taxes became the major component of tax transfers from the Center to the states, which received 87.5 percent of income tax revenues. Unsurprisingly, the Center began to rely increasingly on somewhat ad hoc income tax surcharges, which were not shared.

To correct this and other distortions of the tax structure that seemed to flow from the sharing arrangement, ${ }^{7}$ in 1994 the Tenth Finance Commission recommended an 
alternative, in which a proportion, initially set at 29 percent, of aggregate central tax revenues were be devolved to the states. This proposal required bargaining and agreement among the Center and the states, as well as a constitutional amendment, but this was all accomplished by 2000. Several aspects of this process bear noting. The sequence of reform began with academic proposals that crystallized in the specific recommendation of the Finance Commission, which itself consists of senior policymakers and politicians, advised by academic economists. The next stage involved political bargaining through the Inter-State Council (ISC), which is a closed-door discussion forum that has the Prime Minister, state Chief Ministers, and several central cabinet ministers as members. Once this stage was completed, legislative implementation was relatively routine. This is characteristic of India: logrolling and consensus building take place outside the formal legislative arena, but within wellunderstood institutional parameters

Another feature of this case is worth noting. The reform affected tax sharing between the Center on the one hand, and the states in aggregate on the other. This meant that it was relatively easy to calibrate the new sharing system in a way that left the overall shares of the Center and the states in aggregate near their previous values, avoiding the problem of creating an immediate loser from the reform. To achieve such neutrality in changing the formula by which the states' share is divided among them would obviously be a much harder exercise, though not impossible. This bargaining perspective of feasible reform in India's federal system is useful for considering other potential reforms of India’s intergovernmental transfer system. 
One issue is that of revising the formula used to determine each state's share of the tax revenue devolved from the Center. This formula involves a complex balancing of multiple objectives, and does not give a clear sense of overall impact on interstate (horizontal) equity or on incentives for fiscal prudence (see Table 1). The table indicates, through the example of the last two Finance Commissions, how precedent is respected in this formula, with relatively minor conceptual adjustments being made by each new commission. ${ }^{8}$ The approach illustrated here, of combining disparate concerns, such as equity, efficiency and incentive provision, through a weighting scheme for partial measures of these concerns, is quite different from the normative framework that emerges from the economic theory of public finances in the Musgrave tradition (e.g., Musgrave, 1959; Boadway and Flatters, 1982). Interestingly, practice in Australia and Canada, two other federations with a British colonial history, is closer to the economists' perspective, and formed the basis for a detailed comparison with India by two members of the Twelfth Finance Commission (Rangarajan and Srivastava, 2004a, b). Although this comparison led to no substantive changes in the horizontal sharing formula decided by the Commission, it may serve the purpose of "agenda setting" for policy recommendations and political bargaining, leading to eventual reform in this direction.

The issue of ad hoc grants by the Finance Commission also bears consideration. While grants made beyond the formula-determined shares may be necessitated by extraordinary circumstances such as natural disasters, their routine use to fill claimed expenditure-revenue gaps undermines the states' incentives for fiscal prudence. The Eleventh Finance Commission, making recommendations for the years 2000-05, reversed the practice, started by the Ninth Finance Commission, ${ }^{9}$ of keeping a portion of shareable 
tax revenues from Union excise duties exclusively for allocation among states according to their estimated post-tax-devolution deficits. As we have argued above, an approach that incorporates equity concerns into a formula is preferable to one in which such "gapfilling” grants are made at the margin. However, the latest Finance Commission reduced horizontal equalization weights in the formula, and increased the use of various grants. Thus, there is no clear trend in practice on the treatment of grants and their incentive consequences.

A case for reform of transfer formulae also exists for Planning Commission transfers calculated on the basis of the NDC's consensus formula (Table 2). It can be seen that the Planning Commission formula is similar in construction to that of the Finance Commission, and the same critique is possible. In principle, Planning Commission transfers are for “developmental purposes," including project-specific expenditures - this is a very different rationale from general revenue sharing. In practice, because of fungibility and outright diversion, these transfers have increasingly been used for general expenditure needs, such as salaries and administration. Moving away from previous practice, and more in line with constitutional intent, the last two Finance Commissions were asked to consider India's overall fiscal position. In this context, both commissions criticized the conceptualization and implementation of plan transfers. ${ }^{10}$ The Eleventh Finance Commission specifically recommended a reassessment of plan-transfer formulae, with this task to be brought within the scope of the Finance Commission. Thus, this reform has also been put on the policy agenda, where political debate will now occur. However, unlike the case of changing the Finance Commission transfer formula, this raises a control issue between two components of the government. In the past, the 
Planning Commission, a permanent body, has had greater clout than the more tenuously composed Finance Commission. ${ }^{11}$

\section{REFORM OF INDIA'S FISCAL FEDERAL INSTITUTIONS}

The success of the change in tax-sharing arrangements (sharing all taxes, rather than just a few, between the Center and the states) suggests that reform of India's fiscal federal system is politically feasible and implementable within India's existing institutional framework. However, reforming the formulaic aspects of India's system of Center-state transfers is a relatively narrow, and therefore easier, proposition than other kinds of institutional reform. Nevertheless, there is evidence that broader reforms are also politically feasible. Here we discuss three important aspects of broader institutional reform: tax assignments, decentralization to local governments, and changes in financing methods for state governments’ capital expenditure.

\section{$\underline{\text { Tax Reform }}$}

Tax reform has been proceeding on many fronts since the 1980s - with added impetus from the economic reforms of the 1990s - including reductions in tariff rates, reductions in direct tax rates coupled with attempts to broaden the tax base, and a gradual movement from excise duties and sales taxes to a VAT by both the central and state governments. Comparing 1990-1991 with 2002-2003, the central direct-tax-to-GDP ratio increased from 2.2 percent to 3.7 percent (accompanied by a tripling in the number of tax filers from about 6 to 18 million), but this was more than offset by a decrease in the central indirect-tax-to-GDP ratio from 7.9 percent to 5.3 percent, driven by reductions in 
the percentages of central excise duties as well as customs duties. ${ }^{12}$ State sales taxes and excise duties have also shown some decline, so that the overall tax-GDP ratio declined by almost two percentage points during the 1990s (Rao, 2000b). The fact that this occurred at higher income levels, which would normally support a higher ratio, and that a significant portion of the decline was in domestic indirect taxes in addition to customs duty raises questions about long-term implications. These issues are connected to dimensions of tax reform that have yet to be tackled effectively.

The Tax Reform Committee of 1991 had recommended minimizing exemptions and concessions, simplifying laws and procedures, developing modern, computerized information systems, and improving administration and enforcement. ${ }^{13}$ Subsequent committees (known as the Kelkar committees, after their chair), echoed and amplified these recommendations. However, there has been little progress to date on any except the first of these areas.

Reforms that more directly affect India's federal system pertain to indirect taxes, which, as noted, did not increase proportionately with GDP in the last decade. Evolving a coordinated consumption-tax system remains a major challenge. In the context of problems with the current assignments of indirect taxes, Rao (2000b) provided detailed recommendations with respect to issues such as rates, interstate sales taxes, and tax administration for a dual VAT coordinated between the Center and the states, and noted the problem created by the failure of the Constitution to explicitly include services within the scope of states' sales tax authority. ${ }^{14}$ Moving taxation of services from the Union list, where it implicitly lay through the Center's residual powers over taxes not explicitly specified in the Constitution, would have been one option. Instead, the central 
government chose to explicitly add service taxes to the Union List, via an amendment to the Constitution, passed in January 2004, but still to be enacted. Service taxes are to be shared with the states, in a manner yet to be determined, and outside the common pool that is allocated by the Finance Commission. It is possible that the sharing of service taxes will be completely outside the Commission's scope in the future, representing a reversal of previous measures to simplify the tax-sharing system and make it more efficient.

One can obviously understand this move as an attempt by the Center to increase its own revenues. It is still possible, however, to incorporate political economy considerations: the Center could give up its power to the states, in exchange for their agreement to reduce and eventually eliminate taxation of interstate sales. This would remove some of the internal barriers that have prevented the development of a true national market within India. It would also smooth the implementation of a destinationbased VAT for the states, which in turn could also reduce tax exporting by the richer states (Rao and Singh, 2005, Chapter 7). While considerable recent progress has been made in moving toward a comprehensive VAT, many states have yet to implement this reform.

The issue of taxation of services illustrates a broader issue addressed by the Eleventh Finance Commission. Its report recommended, without giving any specifics, a reduction in the vertical fiscal imbalance by giving the states more power to tax. This approach takes some pressure off the fiscal transfer system, allowing states that can obtain political support to tax their own constituents in a more flexible manner, in order to deliver benefits to them. An example of such a tax reassignment would be to allow 
states to piggyback on central income taxes. Any such reform would also require a constitutional amendment. Piggybacking could give states more flexibility at the margin, adjusting their own tax rates as needed, somewhat independently of tax-sharing allocations. States are already assigned the right to tax agricultural income, but their current use of this tax is minimal. This separation has no economic justification, and, as noted earlier, promotes tax evasion. Piggybacking could be combined with a removal of the distinction between nonagricultural and agricultural income. This would broaden the direct tax base, giving the states a flexible new tax in return for giving up the distortionary and ineffective agricultural income tax.

To summarize, while some tax reform measures can be initiated by the Center acting alone, many others require agreement or coordination between the Center and the states. These include possible reassignments of tax authority, as well as changes in tax administration. Recognizing the play of differing interests may help in devising reform packages that balance potential losses against gains, and thereby increase the probability of acceptance.

\section{Local Government Reform}

The political motivations and history of local government reform in India have been quite different from those that led to the country's economic reforms of the 1990s. Nevertheless, there is a complementarity between the two sets of reforms. After a long history of debate on decentralization, a central government committee recommended that local bodies be given constitutional status. This was accomplished through constitutional amendments in 1993. These amendments required individual states to pass appropriate legislation because local government remained a state subject under the Constitution; and 
all states complied. It has been suggested that the Center pushed through this reform to reduce the power of state governments, ${ }^{15}$ but this may have only been one factor, with genuine sentiment for “democratic decentralization” playing an important role. In any case, states have often been reluctant to devolve authority and revenue to the local level.

A key change brought about by the amendments was a reduction of state government discretion concerning elections to rural local government bodies. Direct elections to local bodies must now be held every five years. This reform replaces "hierarchy" with "voice” as the primary accountability mechanism for local government, potentially improving that accountability. ${ }^{16}$ Local government reform also has changed the nature of tax and expenditure assignments to local governments, and instituted a system of formal state-local transfers by State Finance Commissions (SFCs), modeled on the central Finance Commission.

One view has been that formal transfers from the Center and states to local governments have the potential to accentuate fiscal deficit problems. ${ }^{17}$ However, local government finances, particularly for urban bodies, steadily worsened over the period before local government reform, under supposedly strict monitoring by state governments. ${ }^{18}$ Thus, the formal, rule-governed system now in place may simply have made existing problems more transparent. However, the SFCs have struggled to formulate principles for sharing or assigning state taxes, tolls, and fees and for making grants-in-aid (Finance Commission, 2000, Paragraph 8.11b). This reflects inexperience, but also reluctance on the part of state governments to devolve revenue in this manner. Current assignments of tax authority to the various tiers of rural local government leave them in a weak position, with effectively no fiscal autonomy (World Bank, 2004). In 
some cases, state governments have failed to implement their own SFC reports. Instead, states have asked the central Finance Commission to provide them with additional grants to supplement their own transfers to local governments. The last two commissions have been reluctant to do so, noting that the constitutional amendments do not justify this softening of the states’ budget constraints in this manner.

The recent Finance Commissions’ main recommendations with respect to local government have related to assignment and incentive issues for enhancing revenue. Land and profession taxes, as well as local user charges, were identified as possible sources of revenue enhancement. Perhaps the most promising is the recommendation of surcharges on state taxes earmarked for local government, similar to the piggybacking on central taxes that was proposed for the states earlier in this paper. These recommendations are conceptually straightforward; being based on economic principles of minimizing allocational distortions. The real issues arise in defining details and achieving implementation. State governments, acting on SFC recommendations, have to formulate and agree on such changes. The fiscal weakness of local governments, which these reforms would remedy, puts them in a poor bargaining position to push for change. By contrast, in the case of the central Finance Commission, the bargaining power of the states and the role of precedent have worked to ensure the implementation of most recommendations. In the case of local governments, they may need help from the courts to pressure reluctant state governments.

One factor that may aid the case for local governments to receive more revenue authority is if they can show they are more efficient than the state government at spending the money. This goes back to the idea that local governments may be more 
accountable. The Eleventh Finance Commission suggested a quicker transfer of expenditure responsibilities to local governments; to give them this opportunity, with interim grants to provide initial resources, in the absence of adequate state-local transfers. The commission also recommended grants for improved accounting, auditing, and database building for local governments. These grants are meant to flow directly to local governments, rather than supplementing the states' own transfers. However, there are also potential conflicts between the existing institutional apparatus of central ministry schemes, and the role envisaged for local governments.

Finally, there is a parallel between the nature of past regulation of local governments in India and the previous approach to economic policy, which relied on the case-by-case discretion of government decision-makers. Ideas that are guiding changes in how the national government interacts with the private sector are also important for how state governments interact with local governments. The expanded assignments legislated for local governments, and the increased role for local "voice," together require the state governments to fundamentally change their regulation of local governments underneath them. Expanding the scope of the central Finance Commission in determining Center-state transfers, while reforming the principles it uses, can have the added benefit of giving states a clearer road in achieving this change, with more effective devolution to local governments. Also, central ministry transfers, often meant to be implemented at the local level, swamp local government capacity for action and raising own-revenue (Rajaraman, 2001). Replacing these program-specific transfers with conditional or unconditional grants could allow local governments to function more 
effectively. In this way, local government reform ties in with reform of the Center-state transfer system. $^{19}$

\section{Borrowing Reform}

Consideration of the overall fiscal position of India’s federal system was a significant part of the terms of reference for the last two Finance Commissions. This broadening of scope was motivated by the ongoing issue of fiscal deficits that India has struggled with for the past fifteen years. Furthermore, the problem of fiscal deficits has, to a large extent, been pushed down to the state governments, making it very much an issue of federalism. Fiscal deficits in the states have increased despite the central government's apparent formal authority to strictly control state borrowing. The Center has partly enabled the increase in deficits by using discretionary loans, often with interest subsidies or even ex post conversion of loans to grants, as a way of exercising or responding to political influence (Rao, 2000a). Making things worse than the budget numbers indicate, the states have used public sector enterprises and other off-budget devices to run even larger "true” deficits (Rao, 2000c; Mohan, 2001).

The ultimate enabler of India's continued fiscal deficits has been the nature of its financial system. Financial repression, along with direct ownership and control of much of the financial system, has permitted the central government to "park" deficits in the financial system, avoiding the need to print money and cause politically dangerous inflation. State governments have been able to tap postal savings, ${ }^{20}$ and to borrow from nationalized banks, which are required to hold state government bonds. From this perspective, the larger solution is to free the financial sector from its de facto captive role as a holder of government debt. Even in the absence of major financial sector 
privatization, reform is proceeding toward new mechanisms that will allow state governments to borrow to finance capital expenditure, without undermining incentives to use those funds effectively.

The Eleventh Finance Commission recommended a slew of measures to promote fiscal discipline, including an overall ceiling of 37.5 percent of gross receipts of the Center for all transfers to the states; hard budget constraints for all levels of government with respect to wages and salaries; "greater autonomy along with hard budget constraints for public sector enterprises;” more explicit controls on debt levels for state governments; deficit-reduction-linked grants to states and improvements in budgeting, auditing, and control. ${ }^{21}$ However, goals such as "greater autonomy along with hard budget constraints for public sector enterprises” may be impossible in practice due to political pressures. The Twelfth Finance Commission went considerably further in its recommendations, detailing an approach to reducing the central government's role as a lender to the states by replacing it with market borrowing, as a way to harden the states' budget constraints. This would apply to several channels of central loans, including those through the Planning Commission and central ministries. The Reserve Bank of India is exploring the development of institutions to support this shift to market borrowing, including offering mechanisms, secondary markets for government debt, credit ratings, and methods of regulation and monitoring. Therefore, the case of reforming financing states' capital expenditure through new borrowing mechanisms involves building on reforms already taking place in the financial sector. The Finance Commission's role over the last decade has thus come to include recommending major institutional reforms that transcend a narrow determination of intergovernmental transfers. Note that hardening state budget 
constraints in this dimension must be paralleled by reforms that achieve the same goal for other transfers, as argued in the previous section.

\section{CONCLUSION}

This article has provided an analysis of India's fiscal federal institutions in the context of that country’s economic reform. It has suggested that recent reforms of India's fiscal federal institutions have been driven by greater regional political competition, and have proceeded by a combination of political agenda-setting, technocratic advice, and political bargaining, with new institutions created, and existing federal institutions being adapted, in a climate of overall economic reform. In particular, the Finance Commission, which has existed since the 1950s, has played a greatly expanded role in the last fifteen years. The Inter-State Council, created in 1990, has provided a forum for political bargaining with respect to federal reform issues. A third tier of local governments has been given constitutional status in the 1990s. In this evolving institutional framework, tax reform, decentralization to local governments and institutions governing subnational borrowing have been significant areas of fiscal federal reform processes. Thus, one can be argue that politically feasible reforms in India’s federal system are possible, and the institutional process by which they occur can be identified.

The analysis of the Indian case suggests several aspects of reform for that country. One possibility is that the system of Center-state transfers be simplified, and that the Finance Commission be given a greater role in governing these explicit transfers. Another is that tax reforms can include some realignment of tax assignments to remove anomalies and to reduce the extent of vertical transfers. In these cases, there are some 
possibilities for creating politically feasible policy reform packages. This article also assessed some aspects of local government reform and discussed how reforms of the Center-state transfer system, and of the Planning Commission's role, could aid the effectiveness of local governments. Finally, the discussion of Center-state transfers to was related to the issue of financing states' capital expenditure through more effective borrowing mechanisms.

One final country-specific point is that understanding India's federal system is a vital part of conceptualizing economic reform in India. Shifting the boundary of ownership between state and market is just one aspect of reform. Another dimension involves altering the nature of regulation of the market, moving from case-by-case permission and input control to arm's length regulation and performance-based monitoring. Various kinds of decentralization and delegation, which involve changing the nature of the powers of and interactions among the different levels of government, constitute the third, often most neglected dimension of reform.

India's size, diversity and institutional complexity increase the difficulty of applying lessons from any case study to broader contexts. Nevertheless, the analysis in this article, by tracing aspects of the specific institutional process of reform in various fiscal federal institutions, may be seen as a contribution to understanding the dynamics of federal systems in developing countries, and to modeling the endogeneity of federal institutions (e.g., Rodden, 2006b). 
Table 1: Criteria and Relative Weights for Tax Devolution

Criterion
Weight (\%)

11th Finance Commission
Weight (\%)

12th Finance Commission
1. Population (1971 Census)

2. Income (Distance Method)*

3. Area

4. Index of Infrastructure

5. Tax Effort**

6. Fiscal Discipline***

10

62.5

7.5

7.5

5.0

7.5
25

50

10

0

7.5

7.5

Notes: *The distance method share is given by: $\left(\mathrm{Y}_{\mathrm{h}}-\mathrm{Y}_{\mathrm{i}}\right) \mathrm{P}_{\mathrm{i}} / \Sigma\left(\mathrm{Y}_{\mathrm{h}}-\mathrm{Y}_{\mathrm{i}}\right) \mathrm{P}_{\mathrm{i}}$ where $\mathrm{Y}_{\mathrm{i}}$ and $\mathrm{Y}_{\mathrm{h}}$ represent per capita SDP of the $\mathrm{i}^{\text {th }}$ and the highest income State respectively and $\mathrm{P}_{\mathrm{i}}$ is the population of the $\mathrm{i}^{\text {th }}$ State. Most recently, the average of the three richest states has been used for $Y_{h}$, with positive values being used for those states rather than zero, based on a notional “distance” value.

** Tax Effort $(\eta)$ is estimated as $(\eta)=\left(T_{i} / Y_{i}\right) /\left(0.51 / Y_{i}\right)$ where, $T_{i}$ is the per capita tax revenue collected by the $\mathrm{i}^{\text {th }}$ State and $\mathrm{Y}_{\mathrm{i}}$ is the per capita State domestic product of the $\mathrm{i}^{\text {th }}$ State.

*** Estimated as the improvement in the ratio of own revenue of a state to its revenue expenditures divided by a similar ratio for all States averaged for the period 1966-99 over 1991-1993.

Source: Rao and Singh (2005), Twelfth Finance Commission Report (Finance Commission, 2004) 
Table 2: Planning Commission Formula for Distributing State Plan Assistance

\section{Criteria \\ Distribution weights non-special category states}

1. Population (1971)

60.0

2. Per capita income, of which

25.0

(a) According to the 'deviation' method covering only the States with per capita income below the national average

(b) According to the 'distance' method covering all the non-special category states

3. Fiscal performance,

7.5 of which
(a) Tax effort
2.5
(b) Fiscal management
2.5
(c) National objectives
2.5

4. Special problems

Notes: Non-special category states are all the major states, excluding northern and northeastern border and mountainous states.

\section{References}

Baron, David, and John Ferejohn (1989), Bargaining in Legislatures, American Political Science Review, pp. 1181-1206.

Biswas, Rongili and Sugata Marjit (2000), Political Lobbying and Discretionary Finance in India: An Aspect of Regional Political Influence in a Representative Democracy, working paper, Centre for Studies in Social Sciences, Calcutta. 
Boadway, Robin and Frank Flatters (1982), Equalization in a Federal State: An Economic Analysis, Economic Council of Canada, Ottawa: Canadian Government Publishing House.

Breton, Albert (2000) “Federalism and Decentralization: Ownershp Rights and the Superiority of Federalism”, Publius: The Journal of Federalism, Vol. 30. No. 2 (Spring). pp. 1-16)

Breton, Albert, and Anthony Scott (1978), The Economic Constitution of Federal States, Toronto: Toronto University Press

Robin Burgess and Nicholas Stern (1993), Tax Reforms in India, STICERD Working Paper No. 45, London School of Economics

Cashin, Paul, and Ratna Sahay (1996), Internal Migration, Center-State Grants, and Economic Growth in the States of India, International Monetary Fund Staff Papers, 43, 1, 123-171.

Das-Gupta, Arindam, and Dilip Mookherjee (1998), Incentives and Institutional Reforms in Tax Enforcement: An Analysis of Developing Country Experience, Delhi: Oxford University Press.

Dasgupta, Sugato, Amrita Dhillon and Bhaskar Dutta (2001), Electoral Goals and CentreState Transfers in India, processed, Indian Statistical Institute, New Delhi.

Dixit, Avinash and John Londregan (1998), Fiscal Federalism and Redistributive Politics, Journal of Public Economics, Vol. 68, pp. 153-180.

Finance Commission (2000), Report of the Eleventh Finance Commission 2000-2005, New Delhi: Government of India. 
Finance Commission (2004), Report of the Twelfth Finance Commission (2005-10),

November, http://fincomindia.nic.in/Report of 12th Finance

Commission/index.html

Inman, Robert P. and Daniel L. Rubinfeld (1997), The Political Economy of Federalism, in Perspectives on Public Choice: A Handbook, (ed.) Dennis C. Mueller. Cambridge, U.K., pp. 73-105; New York: Cambridge University Press

Kletzer, Kenneth, and Nirvikar Singh (1997), The Political Economy of Indian Fiscal Federalism, ed., Sudipto Mundle, Public Finance: Policy Issues for India, New Delhi: Oxford University Press, pp. 259-298

Kletzer, Kenneth, and Nirvikar Singh (2000), Indian Fiscal Federalism: Political Economy and Issues for Reform, eds., Satu Kahkonen and Anthony Lanyi, Institutions, Incentives, and Economic Reforms in India, New Delhi: Sage Publications, pp. 37-76.

Mohan, Rakesh (2001), Achieving Higher Economic Growth: The Fiscal Deterrent, paper presented at Stanford Conference on Indian Economic Reform, June.

Musgrave, Richard A. (1959), The Theory of Public Finance, New York: McGraw Hill. Nagaraj, Rayaprolu, Aristomene Varoudakis and Marie-Ange Veganzones (1998), LongRun Growth Trends and Convergence across Indian States, OECD Technical Paper No. 131.

Rajaraman, Indira (2001), “Growth-Accelerating Fiscal Devolution to the Third Tier”, paper presented at NIPFP-DFID-World Bank conference on India: Fiscal Policies to Accelerate Economic Growth, New Delhi, May. 
Rangarajan, C., and D.K. Srivastava (2004a), Fiscal Transfers in Canada: Drawing Comparisons and Lessons, Economic and Political Weekly, Vol. 39, May 8-14, 1897-1909.

Rangarajan, C., and D.K. Srivastava (2004b), Fiscal Transfers in Australia: Review and Relevance to India, Economic and Political Weekly, Vol. 39, August 14-20, 37093722.

Rao, M. Govinda (2000a), Invisible Transfers in Indian Federalism, Public Finance/ Finances Publiques, Vol. 52, No. 3-4, 429-448.

Rao, M. Govinda (2000b), “Tax Reform in India: Achievements and Challenges”, AsiaPacific Development Journal, 7, 2, 59-74.

Rao, M. Govinda (2000c), “Fiscal Decentralization in Indian Federalism”, processed, Institute for Social and Economic Change, Bangalore.

Rao, M. Govinda (1979), “Ideological Factors, Political Stability and Tax Revenue Determination: A Case Study of Four Indian States” Public Finance/Finances Publiques, Vol. XXXIV, No. 1, 114-127.

Rao, M. Govinda and Pratap Jena (2005), Balancing Stability, Equity and Efficiency, Economic and Political Weekly, Vol. 40, July 30-August 5, 3405-3412.

Rao, M. Govinda, Ric Shand and K.P. Kalirajan (1999), Convergence of Incomes across Indian States: A Divergent View, Economic and Political Weekly, Vol. 34, March 27-April 2, 769-778.

Rao, M. Govinda, and Nirvikar Singh (2002), The Political Economy of Center-State Fiscal Transfers in India, Institutional Elements of Tax Design and Reform, ed. John McLaren, Washington DC, World Bank, pp. 69-123. 
Rao, M. Govinda, and Nirvikar Singh (2003), How to Think About Local Government Reform in India, in Economic Reform and the Liberalisation of the Indian Economy: Essays in Honour of Richard T. Shand, ed., K.P. Kalirajan. Edward Elgar., pp. 335-390.

Rao, M. Govinda, and Nirvikar Singh (2005), The Political Economy of Federalism in India, New Delhi, Oxford University Press

Reserve Bank of India (2003), Annual Report, Mumbai: Reserve Bank of India.

Rodden, Jonathan (2006a), Hamilton's Paradox: The Promise and Peril of Fiscal Federalism, New York. Cambridge University Press.

Rodden, Jonathan (2006b), Federalism, Oxford Handbook of Political Economy, ed., Barry Weingast and Donald Wittman, forthcoming, Oxford, Oxford University Press.

Rudolph, Lloyd I., and Susanne Hoeber Rudolph (2001), Iconisation of Chandrababu: Sharing Sovereignty in India’s Federal Market Economy, Economic and Political Weekly, Vol. 36, May 5-11, 1541-1552.

Singh, Nirvikar and T.N. Srinivasan (2005), Indian Federalism, Economic Reform and Globalization, in Jessica Wallack and T.N. Srinivasan, eds., Federalism and Economic Reform: International Perspectives, New York and Cambridge, UK: Cambridge University press, 301-363.

Wallack, Jessica and T.N. Srinivasan (2005), ed., Federalism and Economic Reform: International Perspectives, Cambridge, UK, Cambridge University Press. 
Wibbels, Erik (2005), Federalism and the Market: Intergovernmental Conflict and Economic Reform in the Developing World, New York, Cambridge University Press.

World Bank (1995), India: Recent Economic Developments and Prospects, Washington, D.C., The World Bank.

World Bank (2004), India: Fiscal Decentralization to Rural Governments, Washington, D.C., The World Bank.

AUTHORS' NOTE: This is an extensively revised and updated version of a paper presented at the conference on "India: Ten Years of Economic Reform”, at the William Davidson Institute, University of Michigan. The second author has benefited from the hospitality and support of the Research School of Pacific and Asian Studies at the Australian National University; the National Institute of Public Finance and Policy, New Delhi; and the Stanford Center for International Development at Stanford University. We benefited greatly from the detailed comments and suggestions of the referees and editors of the journal. We are also grateful for financial support from the UCSC Academic Senate. Remaining shortcomings are our responsibility.

\section{Endnotes}

${ }^{1}$ See Rao and Singh (2005) for more institutional detail and a discussion of these issues, as well as statistics quoted here.

${ }^{2}$ The NDC is chaired by the Prime Minister and its members include all cabinet ministers at the Center, Chief Ministers of the states, and members of the Planning Commission. 
${ }^{3}$ See, for example, Rudolph and Rudolph (2001). In a different example, while the Finance Commission uses objective formulae to determine tax sharing, it also makes grants, and it has been suggested that states that are represented in the membership of the commission do relatively well in terms of such awards.

${ }^{4}$ The lower house of the Indian parliament is the only directly elected national legislature, and it is where legislative power resides almost exclusively. The upper house is indirectly elected, and is not powerless, but is quite limited in its role.

${ }^{5}$ In fact, Rao and Singh (2002) showed that these effects extended to Finance Commission transfers as well as to more obviously discretionary transfers.

${ }^{6}$ This was designed to equalize the factory prices of basic inputs throughout the country by differentially subsidizing transportation of minerals. Thus, it favored industrialized states like Maharashtra over natural resource-abundant states like Bihar.

${ }^{7}$ Academics were the first to point out these distortions. See, for example, Burgess and Stern (1993).

${ }^{8}$ As the changes in the percentages in Table 1 illustrate, changes within the conceptual framework may be large. Based on calculations presented in Rao and Jena, 2005, the result of the formula change by itself was a 16.5 percent decrease in Maharashtra's share, and 6-12 percent declines for the three other richest of the major states. Transfers for all the other major states were affected by less than 5 percent by the changes in weights. In most cases, the changes in weights counter-balanced changes that resulted from movements in the component variables, suggesting that stability in shares may have been an implicit goal of the changes in weights. Giving more weight to "Area” benefited the small (mostly mountainous, special category border) states substantially, illustrating the 
sensitivity of the system to the diversity. We are grateful to a referee for emphasizing the latter point.

${ }^{9}$ This was in the main report, covering the years 1990-95. Earlier, the Ninth Commission had, as asked, made recommendations for the single year, 1989-90: thus, exceptionally, its recommendations covered six years rather than five.

${ }^{10}$ A more radical suggestion is to do away with the Planning Commission altogether. Where there is a justification for national coordination because of externalities that cross state borders (e.g., roads and power), different ministries or state governments can negotiate and cooperate. Where there is no such justification, unconditional grants, determined by the Finance Commission, would be appropriate. While such radical reform is highly unlikely, there is considerable debate on the Planning Commission's role in a more market-oriented economy (e.g., Singh and Srinivasan, 2005)

${ }^{11}$ It has been suggested that the Finance Commission could be more effective if provided with ongoing resources for conducting its analyses and making recommendations. Both the last two commissions argue strongly for this. See also Rao and Singh (2005).

12 These figures are derived from Reserve Bank of India (2003), Table 4.6. Direct taxes refer to taxes such as personal and corporate income taxes, which are paid directly by those who owe them, whereas, indirect taxes refer to, for example, sales and excise taxes, which are collected by intermediaries from those who partially bear the tax burden.

${ }^{13}$ See Rao (2000a). Das-Gupta and Mookherjee (1998) detailed the problems with Indian tax administration, in terms of the incentives of both those paying taxes and those enforcing them. 
14 This problem has been recognized for some time, and the Eleventh Finance

Commission also recommended its correction (Finance Commission, 2000).

${ }^{15}$ Atul Kohli made this point to the first author at the conference "Indian National

Economic Policy in an Era of Global Reform: An Assessment", at Cornell University, March 29-30, 1996.

${ }^{16}$ See Rao and Singh (2005), Chapter 13, for references and a more detailed discussion.

${ }^{17}$ An early expression of this concern was in World Bank (1995).

${ }^{18}$ See Rao and Singh (2003) for data and several examples.

${ }^{19}$ A recent study (World Bank, 2004) that focuses on two states in southern India (Karnataka and Kerala) discusses some of these ideas in more detail.

${ }^{20}$ Postal savings are gathered through India's large network of post offices, and provide rural citizens, in particular, with a more accessible alternative to bank deposits. The central government allocates 80 percent of these savings to the state governments where the deposits are made, effectively giving those governments a major borrowing source.

${ }^{21}$ In a related development, the Center and several states have passed "fiscal responsibility” laws, but it remains to be seen how credible these legal commitments are, since penalties for noncompliance are ambiguous or nonexistent. 